\title{
THE INFLUENCE OF PRIMARY PAPER SLUDGE ON CONCRETE PROPERTIES
}

\author{
\#JURGITA MALAISKIENE, OLGA KIZINIEVIC, VIKTOR KIZINIEVIC \\ Laboratory of Composite Materials, Institute of Building Materials, \\ Vilnius Gediminas Technical University, Lithuania \\ "E-mail: jurgita.malaiskiene@vgtu.lt
}

Submitted March 25, 2019; accepted April 27, 2019

\begin{abstract}
Keywords: Primary paper sludge, Waste, Concrete, Compressive strength
The possibilities of primary paper sludge (PS) only dried at $75{ }^{\circ} \mathrm{C}$ from the paper production industry used in concrete composition are discussed. For pursuing the set object, the concrete mixes were chosen where part of the cement content was, in one case, replaced by the PS waste and, in the other case, part of the sand content was replaced by the PS waste. It was found that if $2.5 \%$ of the sand is replaced by the PS waste, the compressive strength of the concrete increases by about $15 \%$, its density decreases by $4 \%$ and the water absorption remains analogous to the reference samples. SEM analysis showed that when the content of the PS waste in the mix does not exceed $7.5 \%$, it adhered well to the cement stone and crystals grew on it. The X-ray images showed that analogous minerals were formed in the tested concrete samples and only their contents were different.
\end{abstract}

\section{INTRODUCTION}

Managing waste is a major challenge for modern society. Many scientists have concentrated on the recycling of waste in civil engineering materials [1]. Paper production waste is classified as non-hazardous waste according to the European List of Waste [2] Because paper production is well-developed in the wide world, huge quantities of the said waste are formed. For example, 11 million tonnes of waste are produced yearly by the European pulp and paper industry, $70 \%$ of which originates from the production of deinked recycled paper; in Japan 5.1 million tonnes PS waste are formed per year [3-5]. Because of this, it is very important to solve this problem and to strive to use paper production waste as a secondary raw material. Scientists are involved in examining the opportunities of using the said waste as an additive to various materials; there are abundant publications on the investigation of the impact of this waste on the properties of heat insulating materials and structural materials in the course of their production.

The PS waste composition consists of organic (cellulose fibres, organic binder) and inorganic materials (calcite, kaolinite, talc, chlorite, mica) and it is high alkalinity material [6-9]. In literature, cellulose and other materials of similar composition are indicated to be cement hardening retarders [10-11], whereas calcite may accelerate the hydration process and affect the formation of hydrates [12-13].

A majority of scientists are involved in the investigation of the impact that paper sludge ash has on the properties of cement mortar and concrete, but it requires a lot of energy. It was found that ash of superhydrophobic paper production waste $(12 \%)$ considerably reduces the water absorption of concrete and reduces its sorptivity by about $80 \%$. When the content of the waste in the mix is increased, the electric conductivity of the concrete decreases. If $8 \%$ of the cement content is replaced by PS waste, the compressive strength of the samples increases considerably; on further increasing the waste content in the mix, the density and the compressive strength begin to decrease [14].

In the work [15], it was found that PS waste acquired its best pozzolanic properties after its heat-treatment at the temperature of $700{ }^{\circ} \mathrm{C}$ for $2 \mathrm{~h}$. Then, if $10 \%$ of the cement content is replaced by the said waste in the cement mixes, the strength of the sample increases by several percent. In their review of the scientific literature on this subject in 2015, Frias et al. [16] showed that other scientists proposed heat-treatment of the said waste at the temperature of $700-800{ }^{\circ} \mathrm{C}$ for ensuring its effective pozzolanic properties also [17]. In the review [16], the scientists show that after processing the paper production waste at the temperature of $650-850{ }^{\circ} \mathrm{C}$, the following key oxides are presented in its chemical composition: $\mathrm{SiO}_{2}$ - from 13.9 to $30.2 \% ; \mathrm{Al}_{2} \mathrm{O}_{3}$ - from 8.3 to $18 \%$; $\mathrm{CaO}$ - from 31.4 to $47.1 \% ; \mathrm{MgO}$ - from 0.5 to $4.0 \%$ [18-23]. The key oxide remains $\mathrm{CaO}$ that while reacting with water at a temperature over $700{ }^{\circ} \mathrm{C}$ transforms into portlandite $\left(\mathrm{Ca}(\mathrm{OH})_{2}\right)$.

Other scientists [24] proposed to use up to $10 \%$ of the paper production waste in low density cement mixes; however, it was established that the said waste reduced the strength of the samples. The impact of paper production waste on the properties of very light cement bricks was investigated in the work [25-26], it was proposed to use the obtained products for internal walls. 
The investigation described by [27-28] shows that paper production waste reduces the compressive strength of normal concrete. However, in the work [29], it is pointed out that paper production waste reduced the strength and durability of the concrete, if the abovementioned waste is used in the mix only; if fly ash is used in addition, the indicators of concrete durability are improved.

The opportunities of using paper production waste not processed at a high temperature were analysed in the paper [30]. In the said work, the scientists show that paper production waste (up to $20 \%$ ) may be used in wood cement boards, if $\mathrm{CaCl}_{2}(5 \%)$ is used in the mix. Because the waste under analysis includes cellulose that has a penchant for retarding the hydration processes, it is useful to neutralise it by adding a concrete hardening accelerator.

The authors [31] analysed the possibilities to use a paper sludge layer as a low permeability barrier on waste landfills. The results of the preliminary geotechnical studies of the PS waste indicate the low strength properties, high compressibility and a low coefficient of permeability. They improved the strength of the composite by using cement or others pozzolanic materials (fly ash, bentonite).

Our previous studies [32] with non-burnt PS waste have shown that by increasing the amount of PS waste in cement mortars, the hydration process is slowed down and the hydration temperature decreases. $20 \%$ PS waste significantly reduces mortar flowability and cone penetration depth. PS waste can be used for mortar mixtures in small amounts - up to $5 \%$, thus, reducing the amount of cement or sand. In this case, the strength of the mortar changes slightly.

The aim of this work is to establish the opportunities of using paper production waste only dried at $75^{\circ} \mathrm{C}$ in concrete mixes, when the $2 / 4$ fraction is used as a fine aggregate (one case) or when the fine fraction $0 / 0.5$ is used to replace a part of cement (the other case). A low temperature has been chosen upon in order to strive for the cost-effective utilisation of large quantities of the waste generated in cement mixtures, because the problems of PS waste utilisation are not resolved and thermal treatment of the waste at a high temperature aggravates its secondary use.

\section{EXPERIMENTAL}

Methodology and Materials

For the formation of the samples, the following raw materials were used: Portland cement CEM I 42.5 R that conforms to the provisions of the EN 197-1 standard. The mineral composition of the cement: $\mathrm{C}_{3} \mathrm{~S}-56.6 \%$, $\mathrm{C}_{2} \mathrm{~S}-16.7 \%, \mathrm{C}_{3} \mathrm{~A}-9.0 \%, \mathrm{C}_{4} \mathrm{AF}-10.6 \%$ and $7.1 \%$ of other components (alkaline sulphates and $\mathrm{CaO}$ ). Its principal characteristics are provided in Table 1 below.

Natural sand that conforms to the provisions of the EN 12620 standard with the maximum particle size of $4 \mathrm{~mm}$ (particle density $2630 \mathrm{~kg} \cdot \mathrm{m}^{-3}$, water absorption $0.62 \%$, bulk density $1660 \mathrm{~kg} \cdot \mathrm{m}^{-3}$ ), a coarse aggregate that conforms to the provisions of the EN 12620 standard with a fraction of $4 / 16$ (particle density $2670 \mathrm{~kg} \cdot \mathrm{m}^{-}$ ${ }^{3}$, water absorption $1.3 \%$, bulk density $1600 \mathrm{~kg} \cdot \mathrm{m}^{-3}$ ), the super-plasticiser Dynamon Xtend, the accelerator Mapefast SA (the characteristics obtained from the manufacturer are provided in Table 2 below) and the paper production waste that will be marked as PS.

The PS waste under discussion is formed in paper production after deinking. The PS waste bulk density of the fraction $0 / 0.5$ is $420 \mathrm{~kg} \cdot \mathrm{m}^{-3}$ and of the fraction $2 / 4$ is $390 \mathrm{~kg} \cdot \mathrm{m}^{-3}$. The image of the microstructure of the PS waste is presented in Figure 1. In the course of the X-ray diffraction analysis, calcite and cellulose were found to be the key minerals in the PS waste. It can be seen from

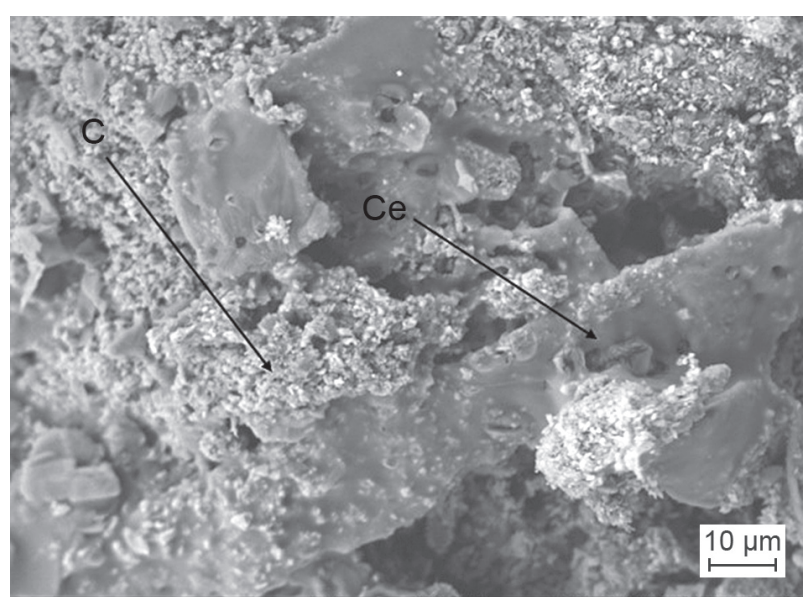

Figure 1. The image of the PS waste microstructure $(\mathrm{C}-$ calcite, $\mathrm{Ce}$ - cellulose).

Table 1. Cement CEM I 42.5 R characteristics.

\begin{tabular}{ccccc}
\hline $\begin{array}{c}\text { Particle density } \\
\left(\mathrm{g} \cdot \mathrm{cm}^{-3}\right)\end{array}$ & $\begin{array}{c}\text { Bulk density } \\
\left(\mathrm{g} \cdot \mathrm{cm}^{-3}\right)\end{array}$ & $\begin{array}{c}\text { Fineness } \\
\left(\mathrm{cm}^{2} \cdot \mathrm{g}^{-1}\right)\end{array}$ & $\begin{array}{c}\text { Compressive strength } \\
\text { after 2 days }(\mathrm{MPa})\end{array}$ & $\begin{array}{c}\text { Compressive strength } \\
\text { after 28 days }(\mathrm{MPa})\end{array}$ \\
\hline 3.1 & 1.1 & 3700 & 22 & 55 \\
\hline
\end{tabular}

Table 2. Properties of the chemical admixes.

\begin{tabular}{lcccr}
\hline Title & Type & Viscosity $(\mathrm{mPaS})$ & Density $\left(\mathrm{kg} \mathrm{m}^{-3}\right)$ & $\mathrm{pH}$ \\
\hline Dynamon Xtend & Liquid & $<30$ & $1060 \pm 20$ & $6.5 \pm 1$ \\
Mapefast SA & Liquid & $<15$ & $1480 \pm 30$ & $6 \pm 1$ \\
\hline
\end{tabular}


the presented image of the microstructure (Figure 1) that the dried PS waste consists of cellulose fibres (with an average width of $15-20 \mu \mathrm{m}$ and length up to $150 \mu \mathrm{m})$ and calcite aggregates.

According to the methodology as per the literature [33], it was found that the PS of the fraction $0 / 0.5$ was an active additive. After seven days of hardening together with lime in air and three days of soaking in water, the samples remained hardened.

Prior to adding to the mixes, the PS waste was dried for $48 \mathrm{~h}$ at the temperature of $75^{\circ} \mathrm{C}$ upon using a laboratory dryer, then crushed by an alligator crusher and sifted through a sieve of relevant fineness. The waste was added to the mixes in the form of a dry powder.

On formation of the mix, the dry raw materials were, first of all, mixed for 1 minute in a mixer. Then the needed quantity of the hardening accelerator was poured into the weighed water and the obtained mix was poured into the mixer. Later the superplasticiser was poured and everything was mixed once more for 2 minutes. When the concrete mix is ready, its slump and density are established.

The concrete samples (with dimensions $100 \times 100 \times$ $\times 100 \mathrm{~mm}$ ) were made and the hardening (to determine strength) was performed according to standard 12390-2. The compressive strength of the concrete samples was determined following the standard EN 12390-3, while the density of the hardened concrete - according to EN 12390-7. The water absorption and the capillary mass flow rate of the concrete samples were established according to the methodology described in the literature [34].

To analyse the microstructure, a scanning electron microscope JEOL JSM-7600F was used: its resolution was $1.5 \mathrm{~nm}$, amplification - from 25 to 1,000,000 times; during the tests, the voltage of $10.0 \mathrm{kV}$ was applied; the surface of the tested samples was covered by gold.

The X-ray diffraction analysis was carried out by the diffractometer DRON-7. The X-ray patterns were encoded according to the reference tables provided in literature, where the values of distance $d$ between the planes and the relative intensity I were assessed. The impact of the PS waste on the cement setting time was established according to standard EN 196-3.

The compositions of the concrete were chosen by replacing a part of the cement content by the waste of the fraction $0 / 0.5$ (the first case is marked as CC) or by replacing a part of the sand content by the waste of the coarse fraction 2/4 (the second case is marked as CS). On choosing the compositions, the results of the earlier research work performed by other scientists, i.e., that the maximum content of the PS waste cannot exceed $20 \%$ and the best effect is usually ensured when the content of the waste is up to $10 \%$, were taken into account. The compositions of the concrete mixes are provided in Table 3 below.

The water/binding materials ratio for all the mixes was 0.5. In the CS4 mix, the contents of the cement and water were increased gradually to ensure the easier formation of the mix because the paper production waste absorbs water rapidly and worsens the workability of the concrete mix.

The data grouping and preparation for the regression analysis was carried out with Microsoft Excel software. A statistical analysis of the researched indicators was carried out as per the literature [35]. This function was selected to determine the mathematical relationship, which describes the data distribution the most precisely, as well as assessing whether the multi-unit correlation and determination ratios are close to one.

\section{RESULTS AND DISCUSSION}

It was found that if the PS waste content in the cement mix is increased, the setting slows down (Figure 2). 15 - $20 \%$ waste content elongates the initial setting time of cement about 3 times and the final setting time - from about 3 to 5 times. For this reason, in the investigation of the concrete the said values were

Table 3. The composition of the concrete per one cubic metre.

\begin{tabular}{|c|c|c|c|c|c|c|c|c|}
\hline Batch & $\begin{array}{l}\text { Waste } \\
(\%)\end{array}$ & $\begin{array}{l}\text { Waste } \\
(\mathrm{g})\end{array}$ & $\begin{array}{l}\text { Cement } \\
(\mathrm{kg})\end{array}$ & $\begin{array}{l}\text { Water } \\
(\mathrm{kg})\end{array}$ & $\begin{array}{l}\text { Superplasticizer } \\
(\mathrm{kg})\end{array}$ & $\begin{array}{l}\text { Accelerator } \\
(\mathrm{kg})\end{array}$ & $\begin{array}{c}\text { Sand } 0 / 4 \\
(\mathrm{~kg})\end{array}$ & $\begin{array}{c}\text { Coarse aggregate } \\
(\mathrm{kg})\end{array}$ \\
\hline $\mathrm{K}$ & 0 & 0 & 320 & 160 & 3.2 & 3.2 & 930 & 1000 \\
\hline \multicolumn{9}{|c|}{ When part of the cement content is replaced by the waste } \\
\hline $\mathrm{CC} 1$ & 5 & 16 & 304 & 160 & 3.2 & 3.2 & 930 & 1000 \\
\hline $\mathrm{CC} 2$ & 10 & 32 & 288 & 160 & 3.2 & 3.2 & 930 & 1000 \\
\hline $\mathrm{CC} 3$ & 15 & 48 & 272 & 160 & 3.2 & 3.2 & 930 & 1000 \\
\hline \multicolumn{9}{|c|}{ When part of the sand content is replaced by the waste } \\
\hline $\mathrm{CS} 1$ & 2.5 & 23 & 384 & 192 & 3.2 & 3.2 & 907 & 1000 \\
\hline $\mathrm{CS} 2$ & 5.0 & 47 & 384 & 192 & 3.2 & 3.2 & 884 & 1000 \\
\hline $\mathrm{CS} 3$ & 7.5 & 70 & 384 & 192 & 3,2 & 3.2 & 860 & 1000 \\
\hline CS4 & 10.0 & 93 & 416 & 208 & 3.2 & 3.2 & 837 & 1000 \\
\hline
\end{tabular}


not assessed anymore because of the slow setting and poor workability; for mixes with a lower content, an accelerator of setting was used. In order to establish the dependence of the setting times on the content of the waste in the mix, empirical equations were formed; in the said equation, the correlation coefficients were close to 1 and the determination coefficients $\mathrm{R}^{2}>0.85$. The signs before the variables in the linear equations show that a higher content of waste causes a longer setting time. It happens because of the weak pozzolanic properties of the waste that as per the literature [15] may be optimised by heat-treatment at the temperature of $700{ }^{\circ} \mathrm{C}$.

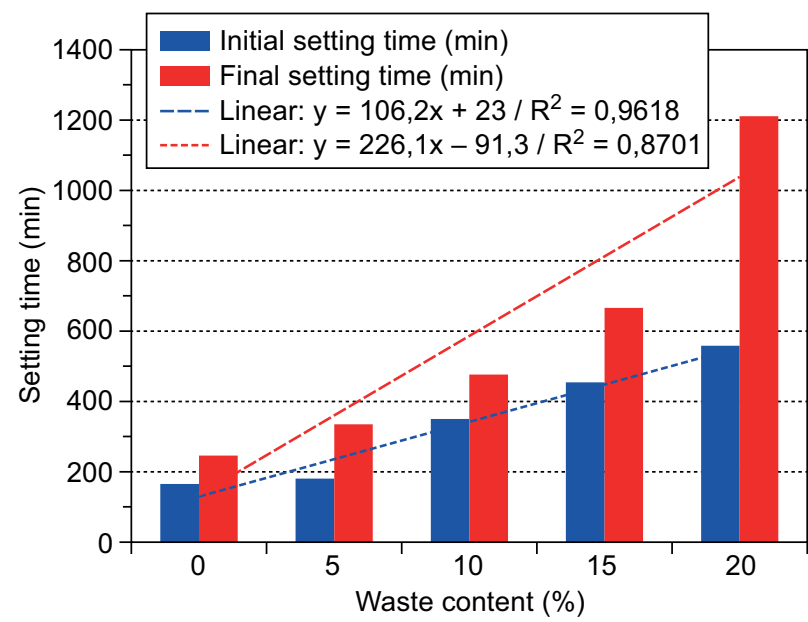

Figure 2. The impact of the PS waste on the setting times of the cement.

The density of the hardened concrete is shown in Table 4. When the content of the PS waste in the concrete mix is increased, the density of the concrete decreases. It could be explained that the bulk density of the PS waste is more less than sand or cement. In addition, it was observed that in the case of the higher content of the PS waste in the mixes, the sizes of the pores and their number in the concrete increase. If part of the sand content in the mix is replaced by the PS waste, the decrease in the density becomes more intensive because of the higher content of the waste $(\mathrm{g})$. The calculations showed that when $10 \%$ of sand content was replaced by PS waste, the density of the concrete samples decreased approximately by $10 \%$; when $5 \%$ of the sand content was replaced by the PS waste - approximately by $5 \%$. When $10 \%$ of the cement content was replaced by the PS waste, the density of the hardened concrete decreased approximately by $5 \%$ and when $5 \%$ of the cement content was replaced by the PS waste, - by approximately $2 \%$.
The water absorption tests (Figures 3,4) showed that the PS waste distinguishes itself for good water absorption and increasing its content in the mix causes higher values of water absorption of the concrete. When part of the cement content is replaced by the PS waste, the water absorption increases uniformly (Figure 3). When part of the sand content is replaced by the PS waste, the changes in the water absorption become step-like. For example, when $2.5 \%$ of the sand content is replaced by the PS waste, the water absorption remains almost the same as that of the reference samples, although the density decreases by about $4 \%$; in such a case, the water absorption is $3 \%$ after $72 \mathrm{~h}$. In the samples where 5 and $7.5 \%$ of the sand content was replaced by the PS waste, the water absorption varies in a very similar way and

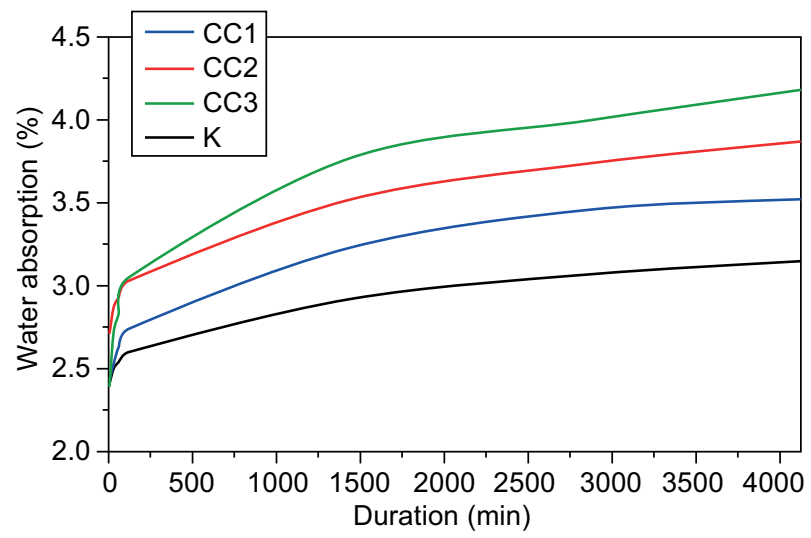

Figure 3. The impact of the PS waste on the water absorption of the concrete when part of the cement content is replaced by the said waste.

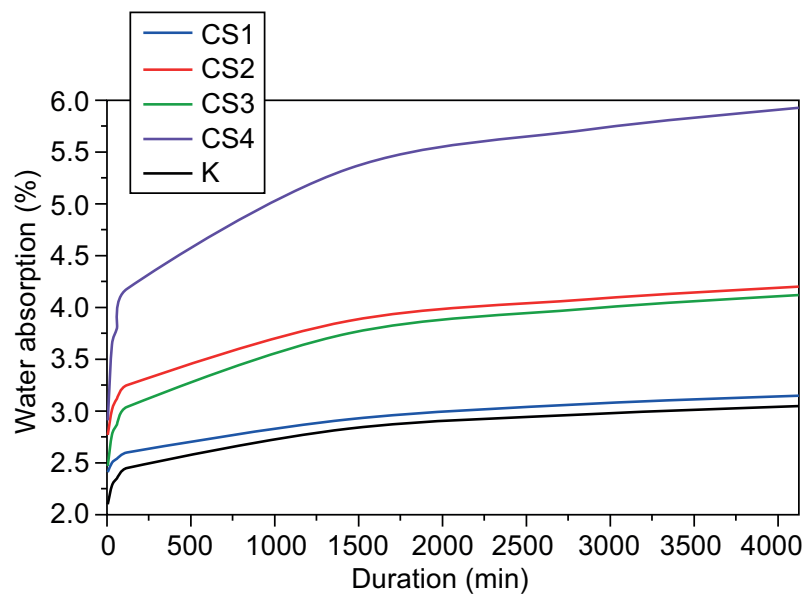

Figure 4. The impact of the PS waste on the water absorption of the concrete when part of the sand content is replaced by the PS waste.

Table 4. Results of the density.

\begin{tabular}{lcccccccc}
\hline Batch & $\mathrm{K}$ & $\mathrm{CC} 1$ & $\mathrm{CC} 2$ & $\mathrm{CC} 3$ & $\mathrm{CS} 1$ & $\mathrm{CS} 2$ & CS3 & CS4 \\
\hline Density $\left(\mathrm{kg} \cdot \mathrm{m}^{-3}\right)$ & 2420 & 2400 & 2380 & 2350 & 2380 & 2330 & 2240 & 2180 \\
\hline
\end{tabular}


becomes equal at approximately $4.1 \%$ after $72 \mathrm{~h}$. The largest jump took place when $10 \%$ of the sand content in the mix was replaced - in such a case, the water absorption was about $6 \%$ after $72 \mathrm{~h}$.

It may be seen from Figures 5 and 6 that an increase in the PS waste causes an increase in the capillary mass flow rate. When $5 \%$ of the cement content is replaced by the PS waste, the capillary mass flow rate remains analogous to the reference sample; if the waste content is increased to $15 \%$, the capillary mass flow rate increases approximately 3 times after 60 and 120 minutes. When 2.5 and $5 \%$ of the sand content is replaced by the PS waste, the capillary mass flow rate increases approximately 2 times after 60 and 120 minutes; and when $10 \%$ of the sand content is replaced by the waste, the capillary mass flow rate increases about 7 times. So, the higher the PS waste content causes the formation of larger quantities of open capillaries. In order to establish the changes to the concrete structure on using the PS waste, a SEM analysis was performed (Figure 7).

It can be seen from Figure 7 that the structures of the concrete provided in the images a), b) and d) are similar. Pores of similar size predominate, the same minerals are identified. In the cavities, needle-shaped ettringite,

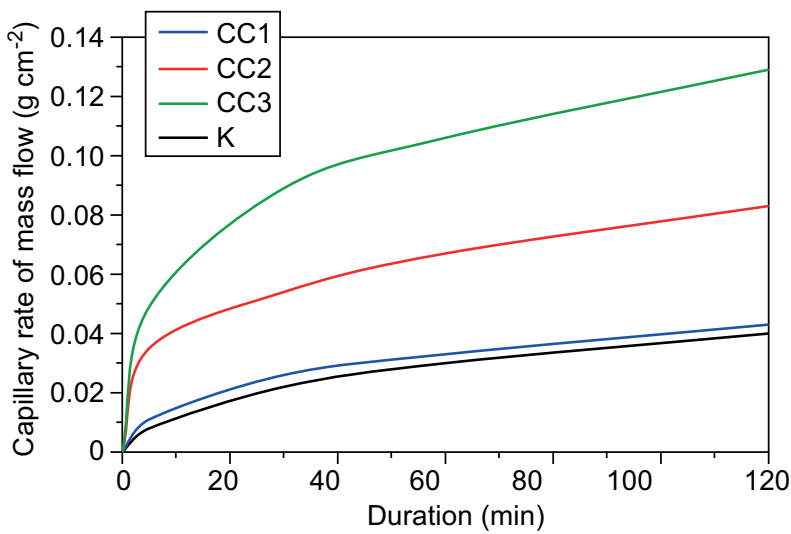

Figure 5. The impact of the PS waste used to replace part of the cement content on the capillary mass flow rate of the concrete.

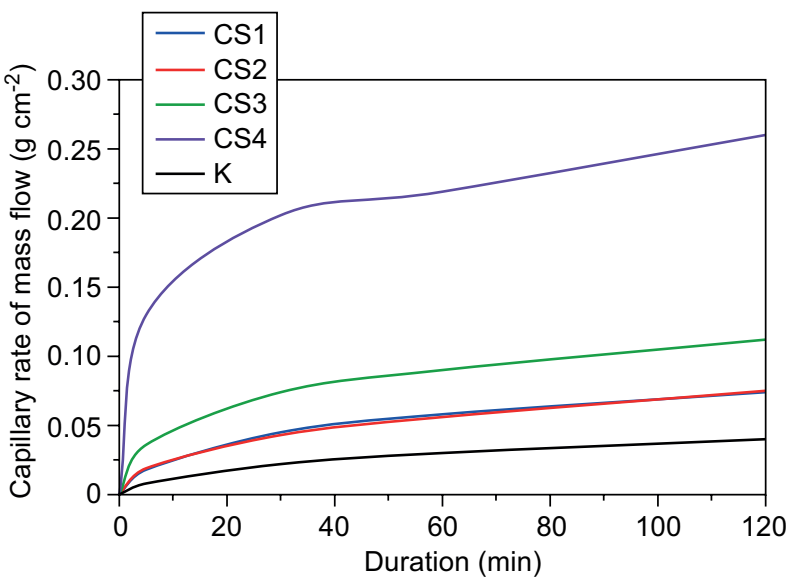

Figure 6. The impact of the PS waste used to replace part of the sand content on the capillary mass flow rate of the concrete. calcium hydrosilicates, hexagonal plates of portlandite and calcite are visible. The PS waste is presented as sticks and splints. When the PS waste content does

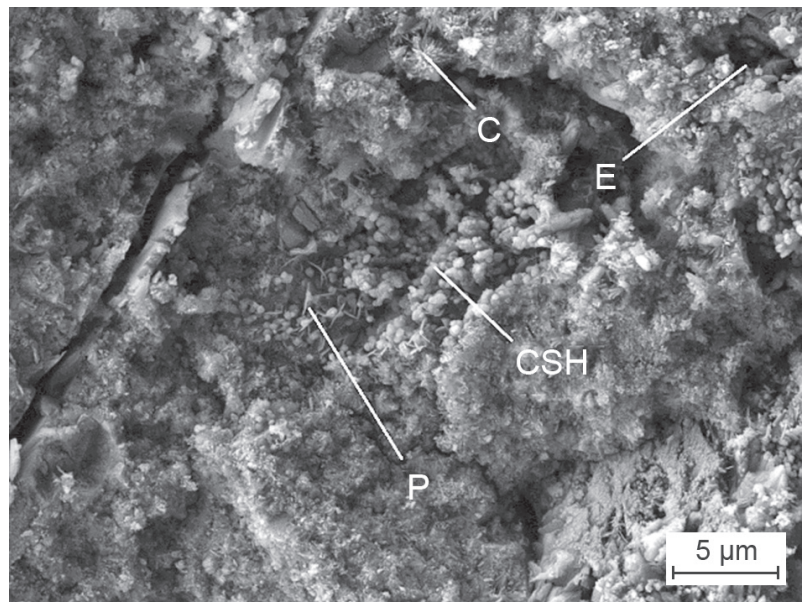

a)

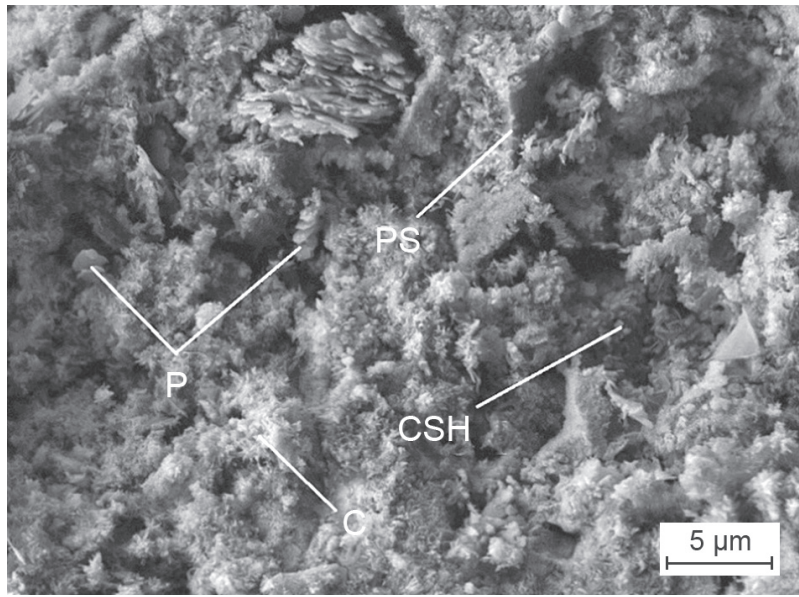

b)

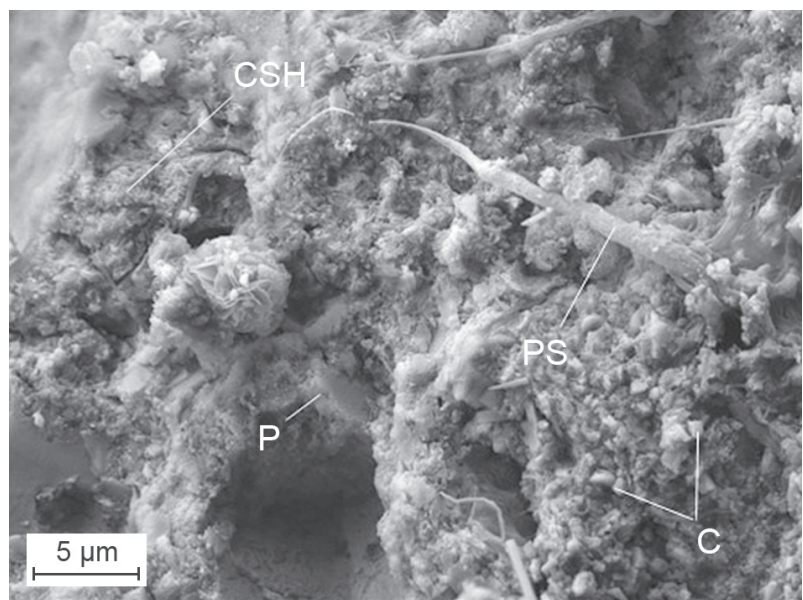

c)

Figure 7. The images of the concrete microstructure: a) concrete without the waste, b) concrete where $5 \%$ of the cement content is replaced by the waste, c) concrete where $15 \%$ of the cement content is replaced by the waste (C - calcite, PS - PS waste, $\mathrm{P}$ - portlandite, $\mathrm{E}$ - ettringite, $\mathrm{CSH}$ - calcium hydrosilicates). (Continue on next page) 


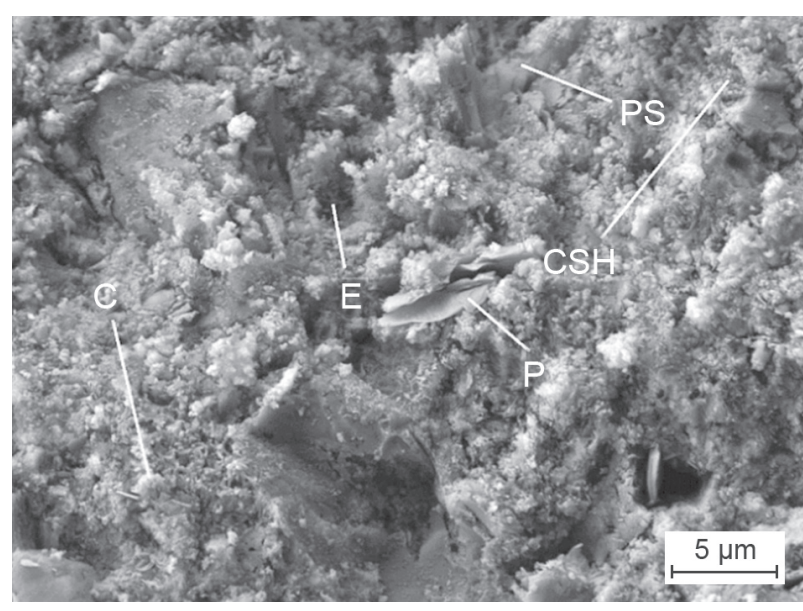

d)

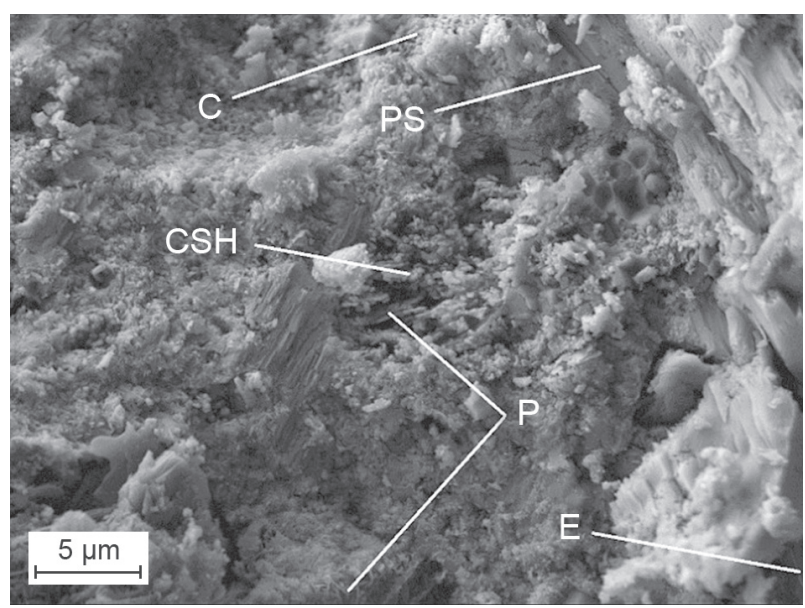

e)

Figure 7. The images of the concrete microstructure: d) concrete where $2.5 \%$ of the sand content is replaced by the waste, e) concrete where $7.5 \%$ of the sand content is replaced by the waste $(\mathrm{C}$ - calcite, $\mathrm{PS}$ - PS waste, $\mathrm{P}$ - portlandite, $\mathrm{E}$ - ettringite, $\mathrm{CSH}$ - calcium hydrosilicates).

not exceed $5 \%$, it is covered with crystals and may be considered one of centres of the crystallisation, because of the good water absortion possibilities. However, when the waste content is increased (c, e), the PS waste is not completely covered by crystals and separate splints of the waste become visible. In such a case, the porosity of the samples and the sizes of the pores increase. When $15 \%$ of the cement content is replaced by the PS waste, the samples are fragile and calcium hydrosilicates are hard to identify. The adhesion between the waste and the cement stone is good, if the waste content is up to $7.5 \%$; in such a case, crystals grow on the PS waste.

The key minerals formed in the structure were established upon applying the X-ray analysis as well. The results are provided in Figure 8 and Table 5 below.

The X-ray analysis confirm that the key minerals formed in the structure include portlandite $\left(\mathrm{Ca}(\mathrm{OH})_{2}\right)$, quartz $\left(\mathrm{SiO}_{2}\right)$, ettringite $\left(3 \mathrm{CaO} \cdot \mathrm{Al}_{2} \mathrm{O}_{3} \cdot 3 \mathrm{CaSO}_{4} \cdot 31 \mathrm{H}_{2} \mathrm{O}\right)$, calcite $\left(\mathrm{CaCO}_{3}\right)$. In addition, alite $\left(3 \mathrm{CaO} \cdot \mathrm{SiO}_{2}\right)$, belite $\left(2 \mathrm{CaO} \cdot \mathrm{SiO}_{2}\right)$ and dolomite $\left(\mathrm{CaMg}\left(\mathrm{CO}_{3}\right)_{2}\right.$ are identified. In the samples of all the compositions, the same minerals were formed; however, the intensity attests to the different contents of them. When the waste was used, particularly low contents of ettringite were obtained. In the concrete with the PS waste, higher calcite contents are visible, as compared to the reference sample. The used waste includes calcite, so if the content of the waste is increased, the content of calcite in the mix increases as well. Some $\mathrm{R} \& \mathrm{D}$ works prove the improvement of the strength of the concrete, if $\mathrm{CaCO}_{3}$ is added to the concrete mixes. For example, scientists [36] found that if $5 \% \mathrm{CaCO}_{3}$ is added to the concrete mixes, the strength of the concrete upon certain conditions increases by about $20 \%$. Other authors found that because of the calcium instability in the wet air at $\mathrm{Rh}>50 \%$, healing of the concrete cracks takes place [37] that may cause a positive impact on the concrete structures. It is supposed that the said effect would be more useful in dry air conditions [38]. In the samples with the PS waste, it decreases the contents of portlandite and $\mathrm{CSH}$ and increases the content of alite. In the samples that replaced the cement by the PS waste, these trends are much higher. By reducing the amount of the cement and adding the PS waste in the mixtures, less CSH is formed and the process of cement hydration slows down.

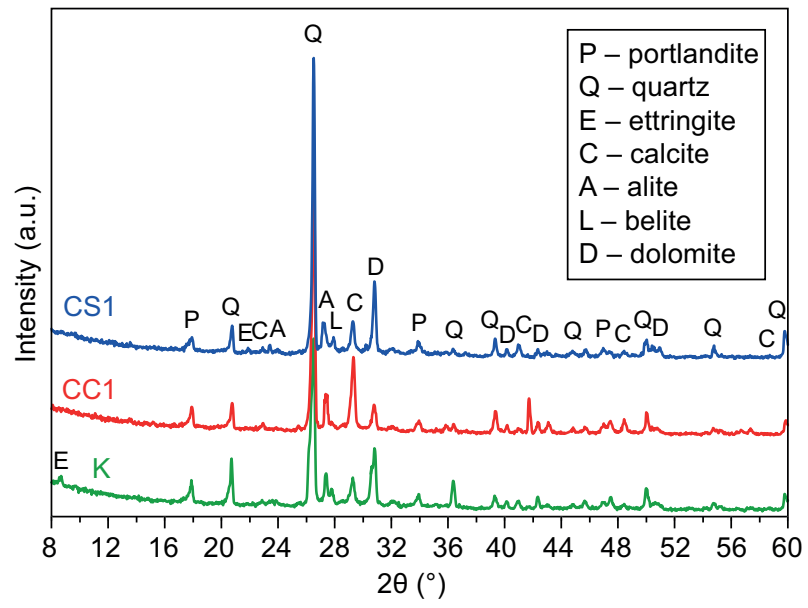

Figure 8. The X-ray of the concrete.

Table 5. The intensities of the main peaks.

\begin{tabular}{cccccc}
\hline Mark & Ettringite & Portlandite & Calcite & CSH & Alite \\
\hline $\mathrm{K}$ & 305 & 287 & 308 & 115 & 321 \\
$\mathrm{CC} 1$ & 250 & 248 & 603 & 94 & 356 \\
$\mathrm{CS} 1$ & 254 & 280 & 340 & 102 & 327 \\
\hline
\end{tabular}

In Figures 9 and 10, the dependence of the compressive strength of the concrete on the waste content in it is shown.

When part of the cement content is replaced by the waste, the linear decrease in the strength of the concrete takes place. The dependences were described 
by the equations where the correlation coefficients and the determination coefficients were very close to one, so it is possible to forecast the compressive strength of the concrete on the basis of the said equations with a low error. After both 28 days and 130 days, the trend of the decrease in the compressive strength of the concrete remains analogous. The minus sign before the first multiplier shows that if the waste content is increased, the compressive strength of the concrete in this case will decrease. It is caused by the negative structural changes, higher water demand and poorer adhesion of the PS waste with the cement matrix. When $5 \%$ of the cement content

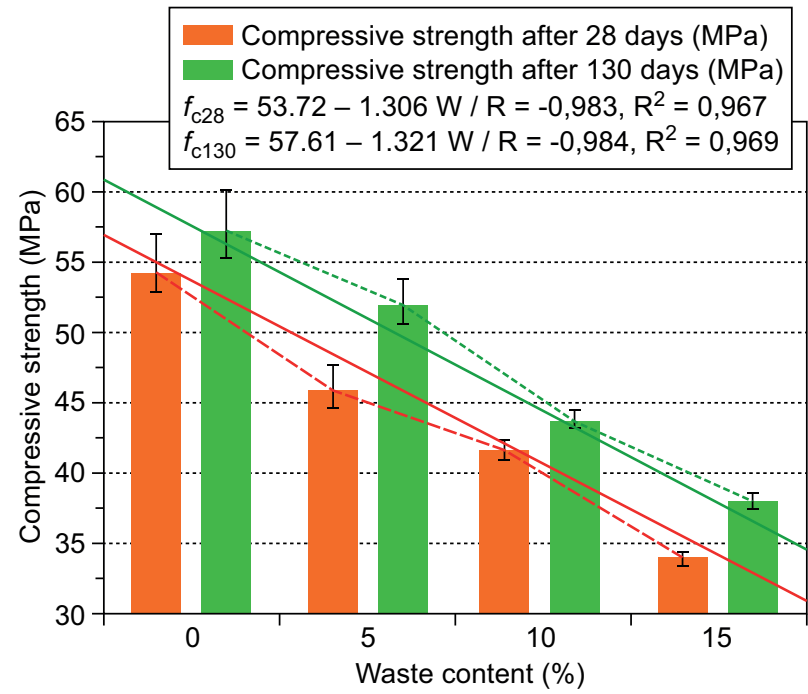

Figure 9. The impact of the PS waste (W) on the compressive strength of the concrete, when part of the cement concrete is replaced by the waste.

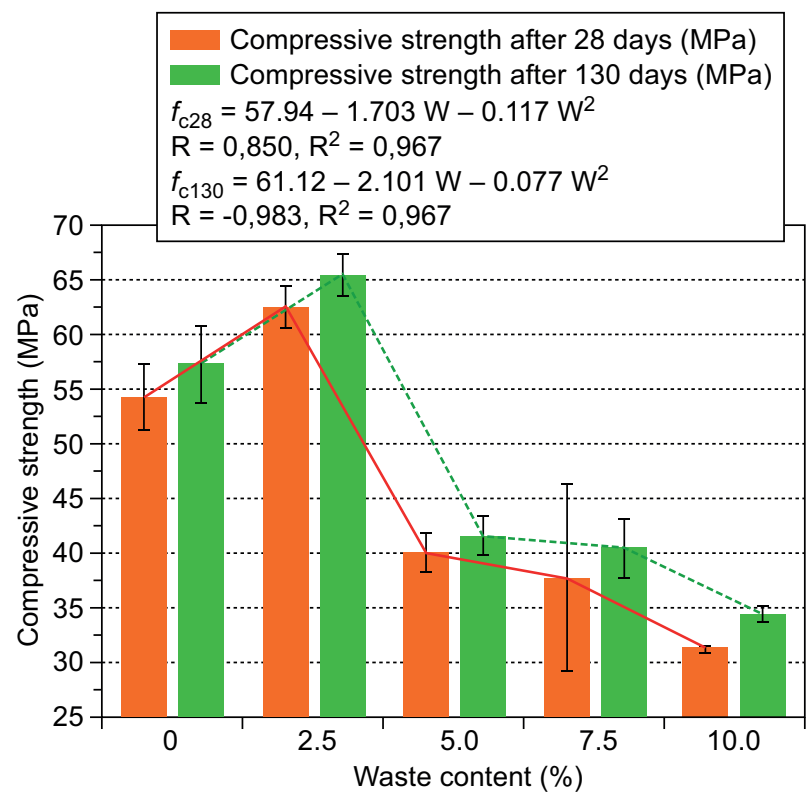

Figure 10. The impact of the PS waste (W) on the compressive strength of the concrete, when part of the sand concrete is replaced by the waste. is replaced by the PS waste, the compressive strength decreases by $15 \%$ after 28 days and by approximately $10 \%$ after 130 days. When $15 \%$ of the cement content is replaced by the PS waste, the compressive strength decreases by $37 \%$ after 28 days and by approximately $34 \%$ after 130 days. After a longer period, the decrease in the compressive strength is less. It may be partially explained by the retard of the hydration process caused by the PS waste.

Another situation is observed, when part of the sand content is replaced by the PS waste. If a small amount $(2.5 \%)$ of the waste is added, the compressive strength increases by about $15 \%$. On further increasing the amount of the PS waste, the compressive strength begins to decrease; when $10 \%$ of sand content is replaced by the PS waste, the compressive strength decreased by about $40 \%$. The closest mathematical model where the correlation coefficients and the determination coefficients are closest to one and the minimum error is obtained is a polynomial of the third degree. In this case, the increase in the compressive strength was caused by the addition of the small amount of the substance having some pozzolanic properties instead of the usual fine aggregate. In addition, in this case (Figure 7d), a dense and defect-free structure of the cement stone where the waste is covered by crystals and is well adhered to the cement matrix was obtained. When the waste content is increased (Figure 7e), the pores increase and more cavities \& cracks appear as well; in such a case, the poorer adhesion of the PS waste to the cement matrix is observed.

On assessment of the obtained results, it was established that the best version would be ensured when $2.5 \%$ of the fine aggregate (sand) is replaced by the PS waste: in such a case, the strength of the concrete increases, the density is reduced and the water absorption remains similar to the absorption of the reference sample.

\section{CONCLUSIONS}

The dried PS waste at $75{ }^{\circ} \mathrm{C}$ is a porous substance where the key components are cellulose and calcite. PS waste retards the initial setting time and the final setting time of the cement stone, reduces the slump of the concrete and the density of the mix. Because the PS waste slows down the hydration process, a setting accelerator or a superplasticiser having such properties should be added to the mixes.

The SEM analysis showed that when the content of the PS waste in the mix does not exceed $7.5 \%$, it adhered well to the cement stone and crystals grew on it. If the content of the PS waste is increased, a scattering of splints is observed, i.e., some splints do not appear to be adhered firmly to the cement matrix. The X-ray analysis showed that analogous minerals were formed in the tested concrete samples and only their contents were different. 
The analysis of the results of the investigation enabled one to establish that application of the dried PS waste at $75^{\circ} \mathrm{C}$ in the concrete production is useful, when $2.5 \%$ of the natural aggregate (sand) is replaced by the said waste. In such a case, the density of the concrete decreases by approximately $4 \%$, as compared to the reference sample, but the compressive strength increases by about $15 \%$ and the water absorption remains analogous.

\section{REFERENCES}

1. Cyr M., Aubert J. E., Husson B., Clastres P. (2006): Management of mineral wastes in cement-based materials. Revue Européenne de Génie Civil, 10, 323-337. Doi: 10.1080/ 17747120.2006.9692831.

2. Siqueira F.B., Holanda J.N.F. (2013): Reuse of grits waste for the production of soil-cement bricks. Journal of Environmental Management, 13, 1-6. Doi: 10.1016/j.jenvman. 2013.09.040.

3. Monte M. C., Fuente E., Blanco A., Negro C. (2009): Waste management from pulp and paper production in the European Union. Waste Management, 29, 293-308. Doi: 10.1016/j.wasman.2008.02.002.

4. Kinoshita, N., Ujike, I., Kawaai, K., Kawaguchi, T., Yasuhara, H., Nagae, T. (2017): Performance evaluation of low carbon concrete using paper sludge ash. Journal of MMIJ 133, 132-139. Doi: 10.2473/journalofmmij.133.132.

5. Bui N. K., Satomi T., Takahashi H. (2019): Influence of industrial by-products and waste paper sludge ash on properties of recycled aggregate concrete. Journal of Clean. Production, 214, 403-418. Doi: 10.1016/j.jclepro.2018.12. 325.

6. Koshikawa M., Isogai A. (2004): Analyses of incinerated ash of paper sludge: comparison with incinerated ash of municipal solid waste. Journal of Materials Cycles and Waste Management 6, 64-72. Doi: 10.1007/s10163-0030104-8.

7. Wajima T., Rakovan J.F. (2013): Removal of fluoride ions using calcined paper sludge. Journal of Thermal Analysis and Calorimetry 113, 1027-1035. Doi: 10.1007/s10973012-2897-y.

8. Hojamberdiev M., Kameshima Y., Nakajima A., Okada K., Kadirova Z. (2008): Preparation and sorption properties of materials from paper sludge. Journal of Hazardous Materials 151, 710-719. doi:10.1016/j.jhazmat.2007.06.058.

9. Mladenovič A., Hamler S., Zupančič N. 2017: Environmental characterisation of sewage sludge/paper ash-based composites in relation to their possible use in civil engineering. Environmental Science and Pollution Research, 24, 1030-1041. Doi: 10.1007/s11356-016-7843-2.

10. Hong H., Xiao-Dong S. (2014): Interaction effect of triisopropanolamine and glucose on the hydration of Portland cement. Construction and Building Materials, 65, 360-366. Doi: 10.1016/j.conbuildmat.2014.04.077.

11. Cao Y., Tian N., Bahr D., Zavattieri P. D., Youngblood J., Moon R. J., Weiss J. (2016): The influence of cellulose nanocrystals on the microstructure of cement paste. Cement and Concrete Composites, 74, 164-173. Doi: 10.1016/j. cemconcomp.2016.09.008.

12. Kakali G., Tsivilis S., Aggeli E., Bati M. (2000): Hydration products of $\mathrm{C}_{3} \mathrm{~A}, \mathrm{C}_{3} \mathrm{~S}$ and Portland cement in the presence of $\mathrm{CaCO}_{3}$. Cement and Concrete Research, 30, 1073-1077. Doi: 10.1016/S0008-8846(00)00292-1.
13. Weerdt K. D., Haha M. B., Saout G. L., Kjellsen K.O., Justnes H., Lothenbach B. (2011): Hydration mechanisms of ternary Portland cements containing limestone powder and fly ash. Cement and Concrete Research, 41, 279-291. Doi: 10.1016/j.cemconres.2010.11.014.

14. Wong H.S., Barakat R., Alhilali A., Saleh M., Cheeseman C.R. (2015): Hydrophobic concrete using waste paper sludge ash. Cement and Concrete Research, 70, 9-20. Doi: 10.1016/j.cemconres.2015.01.005.

15. Garcia R., Villa R.V., Vegas I., Frias M., Rojas M.I.S. (2008): The pozzolanic properties of paper sludge waste. Construction and Building Materials, 22, 1484-1490. Doi: 10.1016/j.conbuildmat.2007.03.033

16. Frias M., Rodríguez O., Rojas M.I.S. (2015): Paper sludge, an environmentally sound alternative source of MK-based cementitious materials. A review. Construction and Building Materials, 74, 37-48. Doi: 10.1016/j.conbuildmat. 2014.10.007.

17. Pera J., Amrouz A. (1998): Development of highly reactive metakaolin from paper sludge. Advanced Cement Based Materials, 7(2), 49-56. Doi: 10.1016/S1065-7355 (97)00016-3.

18. Banfill P., Frias M. (2007): Rheology and conduction calorimetry of cement modified with calcined paper sludge. Cement and Concrete Research, 37(2), 184-190. doi:10.1016/j.cemconres.2006.11.013.

19. Ferreiro S., Blasco T., Rojas M.I.S., Frias M. (2009): Influence of activated art paper sludge-lime ratio on hydration kinetics and mechanical behavior in mixs cured at 20 degrees. Journal of American Ceramic Society, 92(12), 3014-3021. Doi: 10.1111/j.1551-2916.2009.03334.x.

20. Frias M., Garcia R., Vigil R., Ferreiro S. (2008): Calcination of art paper sludge waste for the use as a supplementary cementing material. Applied Clay Sciences 42(1-2), 189-193. Doi: 10.1016/j.clay.2008.01.013.

21. Frias M., Vigil R., Garcia R., Rodriguez O., Goni S., Vegas I. (2012): Evolution of mineralogical phases produced during the pozzolanic reaction of different metakaolinite by-products: influence of the activation process. Applied Clay Sciences 56, 48-52. Doi: 10.1016/j.clay.2011.11.022.

22. Segui P., Aubert J.E., Husson B., Measson M. (2012): Characterization of wastepaper sludge ash for its valorization as a component of hydraulic binders. Applied Clay Sciences, 57, 79-85. Doi: 10.1016/j.clay.2012.01.007.

23. Vegas I., Urreta J., Frias M., Garcia R. (2009): Freezethaw resistance of blended cements containing calcined paper sludge. Construction and Building Materials, 23(8), 2862-2868. Doi: 10.1016/j.conbuildmat.2009.02.034.

24. Wu H., Huang B., Shu X., Yin J. (2016): Utilization of solid wastes/by products from paper mills in Controlled Low Strength Material (CLSM). Construction and Building Materials, 118, 155-163. Doi: 10.1016/j.conbuildmat.2016. 05.005 .

25. Rajput D., Bhagade S.S., Raut S.P., Ralegaonkar R.V., Mandavgane S.A. (2012): Reuse of cotton and recycle paper mill waste as building material. Construction and Building Materials, 34, 470-475. Doi: 10.1016/j.conbuildmat.2012. 02.035 .

26. Raut S.P., Rohant S., Sunil D., Ralegaonkar R.V., Mandavgane S.A. (2012): Reuse of recycle paper mill waste in energy absorbing light weight bricks. Construction and Building Materials, 27, 247-51. Doi: 10.1016/j. conbuildmat.2011.07.053. 
27. Mohammed B., Fang O.C., Hossain K.M.A, Lachemi M. (2012): Mix proportioning of concrete containing paper mill residuals using response surface methodology. Construction and Building Materials, 35, 63-68. Doi: 10.1016/j.conbuildmat.2012.02.050.

28. Chun Y., Naik T.R. (2005): Concrete with Paper Industry Fibrous Residuals: Mix Proportioning. Materials Journal, 102(4), 237-243.

29. Mohammed B.S., Fang O.C. (2011): Mechanical and durability properties of concretes containing paper-mill residuals and fly ash. Construction and Building Materials 25, 717-725. Doi: 10.1016/j.conbuildmat.2010.07.015.

30. Cavdar D., Yel H., Boran S., Pesman E. (2017): Cement type composite panels manufactured using paper mill sludge as Filler. Construction and Building Materials, 142, 410-416. Doi: 10.1016/j.conbuildmat.2017.03.099.

31. Kortnik J., Černec F., Hrast K. (2008): Paper Sludge Layer as Low Permeability Barrier on Waste Landfills. Soil \& Sediment Contamination, 17, 381-392. Doi: 10.1080/15320 380802146586.

32. Malaiskiene J., Kizinievic O., Kizinievic V., Boris R. (2018): The impact of primary sludge from paper industry on the properties of hardened cement paste and mortar.
Construction and Building Materials, 172, 553-561. Doi: 10.1016/j.conbuildmat.2018.04.011.

33. Martusevicius M., Kaminskas R., Mituzas J.A. (2002). Chemical technology of binder materials [Rišamuju medžiagų cheminè technologija]. Kaunas: Technologija. (in Lithuanian).

34. Maciulaitis R. (1996). Frost resistance and durability of facade bricks. Vilnius: Technika.

35. Williams F., Monge P. (2001). Reasoning with Statistics. Cengage Learning.

36. Madrid M., Orbe A., Rojí E., Cuadrado J. (2017): The effects of by-products incorporated in low-strength concrete for concrete masonry units. Construction and Building Materials, 153, 117-128. Doi: 10.1016/j.conbuildmat.2017. 07.086 .

37. Ranaivomanana H., Verdier J., Sellier A., Bourbon X. (2013): Sealing process induced by carbonation of localized cracks in cementitious materials. Cement and Concrete Composites, 37, 37-46. Doi: 10.1016/j.cemconcomp.2012. 12.008 .

38. Piasta W. (2017): Analysis of carbonate and sulphate attack on concrete structures. Engineering Failure Analysis, 79, 606-614. Doi: 10.1016/j.engfailanal.2017.05.008. 